\title{
EIX: A Resource for Entrepreneurship Educators and Their Students
}

David Deeds (University of St. Thomas)

KEYWORDS: Entrepreneurship, Innovation, Research Methods, Teaching Methods, Internet Business Models.

Are you looking for high-quality new material to enrich your entrepreneurship courses and freshen up the syllabus? Are you tired of making students pay for subscription resources? Do your students need some inspiration and direction to help them take their business ideas to a competition?

Entrepreneur and Innovation Exchange (https://eiexchange.com/) and Familybusiness.org (https://familybusiness.org/) have libraries of commentaries, case studies, exercises, practitioneroriented articles and video interviews with great entrepreneurs. All are interesting, useful and perhaps the best part, free. These resources are made possible by the Richard M. Schulze Family Foundation (https://www.schulzefamilyfoundation.org/) -- a charitable venture established by Best Buy Founder Dick Schulze. One of Dick's missions is to improve the success rate of new businesses, and we strive to bring new and aspiring entrepreneurs the best information possible about running a business successfully. Dick also realizes the important role of educators in supporting new entrepreneurs, which is why other articles focus on teaching methods and classroom exercises. And an initiative that launched in 2017, eFest, is a business idea competition specifically for undergraduates. Our 2019 competition (https://eiexchange.com/content/402-georgia-stateteam-is-efest-2019-grand-prize-win) celebrated 25 student finalist teams and awarded more than $\$ 250,000$ to the top three and their universities.

Along with providing resources for students and teachers, we are also looking to publish interesting work. If you would like to publish your research on entrepreneurship or share ideas about what worked in your classroom, please explore EIX and consider it as your outlet. All submissions are peer-reviewed.

The links below provide direct access to some of our popular interviews, articles and cases and to articles about e-Fest. To browse our entire growing collection of learning resources click here (https://eiexchange.com/learning-resources) .

\section{Video interviews}

eFest2018 Winner is Making Life More Colorful for Diabetics

(https://eiexchange.com/content/efest-201 8-winner-is-making-life-more-colorful-fordiabetics?search=efest) Mission-Driven Startup Helps Abuse Survivors

(https://eiexchange.com/content/mission-d riven-startup-helps-abuse-

survivors?search=efest)

Park \& Diamond: eFest2017 Winner Ready to Launch

(https://eiexchange.com/content/Park-andDiamond-efest2017-winner-ready-tolaunch)

More Women Should Study

Entrepreneurship

(https://eiexchange.com/content/morewomen-should-study-entrepreneurship) B-School Students Put New Restaurant on the Map (https://eiexchange.com/content/112-b-sch ool-students-put-new-restaurant-on-themap?search=)
A Father/Son Sitdown: Howard and Steven Aldrich
(https://eiexchange.com/content/193-a-fath erson-sitdown-howard-and-steven- 
aldrich)

Delivering the Goods: An Interview with Best Buy Founder Dick Schulze (https://eiexchange.com/content/6-deliveri ng-the-goods-an-interview-with-best-buyand-eix-founder-dick-schulze)

\section{Articles}

Case Studies, Movies, TV Shows and Other Family Business Resources (https://familybusiness.org/content/case-s tudies-movies-tv-shows-and-other-familybu) by Alfredo DeMassis and Josip Kotlar Innovation Challenge Engages Students at a Commuter School

(https://eiexchange.com/content/374-innov ation-challenge-engages-students-at-acommu) by Jing Betty Feng

Shifting Entrepreneurial Thinking Into High Gear (https://eiexchange.com/content/196-shifti ng-entrepreneurial-thinking-into-highgear) by Mark Spriggs

Entrepreneurship's Moral Minefields: A Conversation with Steve Blank (https://eiexchange.com/content/382-entre preneurships-moral-minefields-aconversatio) by Catherine Buday From Entitlement to Contribution (https://familybusiness.org/content/Fromentitlement-to-contribution) by Robert Caldwell

"Tommie Tank" Helps Students Learn to Finance Ventures

(https://eiexchange.com/content/296-tomm ie-tank-helps-students-learn-to-financevent) by Jay Ebben STEM Students and Faculty Can Gain Entrepreneurial Thinking and Skills (https://eiexchange.com/content/321-Stem -students-and-faculty-can-gainentrepreneuri) by Carla Pavone Action Exercises Engage Students More
Fully than Lectures and Exams (https://eiexchange.com/content/348-actio n-exercises-engage-students-more-fullythan) by James Wetherbe

Teaching Innovation with the Film "Objectified" (https://eiexchange.com/content/206-teach ing-innovation-with-the-film-objectified) by Daniel Forbes

Educating the Unintended Entrepreneur (https://eiexchange.com/content/344-Educ ating-the-Unintended-Entrepreneur?searc $\mathrm{h}=$ education\%20and\%20teaching) by Roy Carriker

Small Acts of Entrepreneurship Transcend the Business Realm (https://eiexchange.com/content/337-small -acts-of-entrepreneurship-transcend-thebus?search=small\%20acts) by Donna DeCarolis

Social Entrepreneurship Exercise: Developing Your Theory of Change (https://eiexchange.com/content/289-socia I-entrepreneurship-exercise-developingyour) by Sophie Bacq Confidentiality Agreements Promote Candor in Family Business Classes (https://familybusiness.org/content/confid entiality-agreements-promote-candor-infam) by Kimberly Eddleston and Devina Raithatha

How New Businesses Can Improve Their Chance of Survival (https://eiexchange.com/content/270-hownew-businesses-can-improve-theirchances-of-survival) by Howard Aldrich Entrepreneurship Education Must Start Before College (https://eiexchange.com/content/291-entre preneurship-education-must-start-beforecol?search=education\%20and\%20teachin g) by Roy Carriker

Want to Give Your Students Real-World 
Experience? Try Consulting Projects (https://eiexchange.com/content/88-want-t o-give-your-entrepreneurship-students-re al-world-experience-try-consultingprojects) by Kim Eddleston

Why Didn't I Think of That? A Classroom Exercise for Developing Entrepreneurial Thinking (https://eiexchange.com/content/32-why-di dnt-i-think-of-that-a-classroom-exercise-f) by Dan Holland

Should I Participate in a Business Accelerator?

(https://eiexchange.com/content/78-shouldi-participate-in-a-business-accelerator) By Jon Eckhardt

Entrepreneurs are Built, Not Born (https://eiexchange.com/content/110-entre preneurs-are-built-not-born) by Ron Mitchell

Every College Student Should Take a Course in Entrepreneurship (https://eiexchange.com/content/245-every -college-student-should-take-a-course-inentrepreneurship) by Sara Cochran Entrepreneurship Programs Should Nurture Companies of One (https://eiexchange.com/content/39-entrep reneurship-programs-should-nurturecompanies-of-one) by George Gendron e-Fest

Home Page with Last Year's Winners (https://eiexchange.com/e-fest)

e-Fest Rules(https://eix.org/e-festguide/faqs/)

Turning Good Presentations into Great Ones (https://eiexchange.com/content/127-turni ng-good-business-presentations-intogreat-ones) by Joan Moser

EIX is a non-profit organization that is funded by the
Schulze Foundation to promote entrepreneurship (more about EIX(https://eiexchange.com/about) ). While we post free displays of entrepreneurship schools where our editors teach, we do not sell or accept paid ads. Nor do we sell or provide your information or your students' information to any other organizations. Please explore the site and consider including our content in your courses and publishing your research, insights and best practices in the classroom on EIX.

Please direct inquiries about using or submitting content to: info@eiexchange.com

(mailto:info@eiexchange.com)

All the best,

David Deeds

Editor-in-Chief

Entrepreneurship and Innovation Exchange

Additional Search Terms: tools for teachers, resources for teachers, resources for professors, business schools, entrepreneurship schools, teaching entrepreneurship, classroom resources 